\title{
GLUCOCOVID: A controlled trial of methylprednisolone in adults hospitalized with COVID-19 pneumonia
}

Luis Corral-Gudino ${ }^{1}$, Alberto Bahamonde ${ }^{2}$, Francisco Arnaiz-Revillas ${ }^{3}$, Julia Gómez-Barquero ${ }^{4}$, Jesica Abadía-Otero ${ }^{4}$, Carmen García-Ibarbia ${ }^{5}$, Víctor Mora ${ }^{6}$, Ana Cerezo-Hernández ${ }^{7}$, José L. Hernández ${ }^{5}$, Graciela López-Muñíz ${ }^{7}$, Fernando Hernández-Blanco ${ }^{2}$, Jose M. Cifrián ${ }^{6}$, Jose M. Olmos ${ }^{5}$, Miguel Carrascosa ${ }^{8}$, Luis Nieto ${ }^{9}$, María Carmen Fariñas ${ }^{3}$, and José A. Riancho ${ }^{5}$, for the GLUCOCOVID investigators*

1. Servicio de Medicina Interna, Hospital Rio Hortega, Universidad de Valladolid. Valladolid, Spain

2. Servicio de Medicina Interna. Hospital Bierzo. Ponferrada, Spain

3. Servicio de Enfermedades Infecciosas. Hospital U M Valdecilla, Universidad de Cantabria, IDIVAL. Santander, Spain

4. Servicio de Medicina Interna, Consulta de Enfermedades Infecciosas, Hospital Rio Hortega, Universidad de Valladolid. Valladolid, Spain

5. Servicio de Medicina Interna. Hospital U M Valdecilla, Universidad de Cantabria, IDIVAL. Santander, Spain

6. Servicio de Neumología. Hospital U M Valdecilla, Universidad de Cantabria, IDIVAL. Santander, Spain

7. Servicio de Neumología. Hospital Universitario Río Hortega, Valladolid, Spain.

8. Servicio de Medicina Interna. Hospital Laredo. Laredo, Spain

9. Servicio de Medicina Interna. Hospital Sierrallana. Torrelavega, Spain

\section{Running title:}

Short course corticosteroids in COVID-19

\section{Keywords}

SARS virus; COVID-19 drug treatment; glucocorticoids; pragmatic clinical trial; treatment outcome

\section{Corresponding author}

José A. Riancho. Department of Medicine. Hospital U M Valdecilla, University of Cantabria

Santander, Spain

Tel +34942203364

Fax +34942201990

Email: rianchoj@unican.es; joseantonio.riancho@scsalud.es

\section{*GLUCOCOVID INVESTIGATORS}

Hospital Bierzo: Alberto Bahamonde, Fernando Hernández-Blanco, Cristina Buelta-González, Luis A. MarcosMartínez, Ana I. Martínez-Vidal, Pilar R.I Dosantos-Gallego, Jesús Pérez-Sagredo, Silvia Sandomingo-Freire. Rebeca Muñumer-Blázquez, Antonio Paredes-Mogollo, Elena Brague-Allegue

Hospital Laredo: Miguel Carrascosa, Juan L. García-Rivero. Hospital UM Valdecilla: José A. Riancho, José M. Olmos, Carmen Fariñas, José M. Cifrian, Carmen García-Ibarbia, Jose L. Hernández, Francisco Arnaiz-Revillas, Victor Mora, Sara Nieto, Juan Ruiz-Cubillán, Arancha Bermúdez, Javier Pardo, Carlos Amado, Andrés Insunza, Aritz Gil, Teresa Diaz-Terán, Marina Fayos, Miguel A. Zabaleta, Juan J. Parra. Hospital Rio Hortega: Luis Corral-Gudino, Julia GómezBarquero, Jesica Abadía-Otero, Ana Cerezo-Hernández, Graciela López-Muñíz, Angela Ruíz-de-Temiño-de-la-Peña, C. Ainhoa Arroyo-Domingo, Javier Mena-Martín, Pablo Miramontes-González, Ana E Jiménez-Masa, Luis PastorMancisidor, Tanía M Álvaro-de-Castro, María Cruz Pérez-Panizo, Tomás Ruíz-Albi, C Gema de-la-Colina-Rojo, María Andrés-Calvo, Andrea Crespo-Sedano, Begoña Morejón-Huerta, Laisa S. Briongos-Figuero, Julio F Frutos-Arriba, Javier Pagán-Buzo, Miriam Gabella-Martín, Marta Cobos-Siles, Ana Gómez-García. Hospital Sierrallana: Luis Nieto 
medRxiv preprint doi: https://doi.org/10.1101/2020.06.17.20133579; this version posted June 18, 2020. The copyright holder for this preprint (which was not certified by peer review) is the author/funder, who has granted medRxiv a license to display the preprint in perpetuity.

All rights reserved. No reuse allowed without permission.

\section{ABSTRACT}

Background. We aimed to determine whether a 6-day course of intravenous methylprednisolone (MP) improves outcome in patients with SARS CoV-2 infection at risk of developing Acute Respiratory Distress Syndrome (ARDS).

Methods. Multicentric, partially randomized, preference, open-label trial, including adults with COVID-19 pneumonia, impaired gas exchange and biochemical evidence of hyper-inflammation. Patients were assigned to standard of care (SOC), or SOC plus intravenous MP [40mg/12h 3 days, then $20 \mathrm{mg} / 12 \mathrm{~h} 3$ days]. The primary endpoint was a composite of death, admission to the intensive care unit (ICU) or requirement of non-invasive ventilation (NIV).

Results. We analyzed 85 patients (34, randomized to MP; 22, assigned to MP by clinician's preference; 29, control group). Patients' age (mean $68 \pm 12 \mathrm{yr}$ ) was related to outcome. The use of MP was associated with a reduced risk of the composite endpoint in the intention-to-treat, age-stratified analysis (combined risk ratio -RR- 0.55 [95\% $\mathrm{Cl} 0.33-0.91] ; \mathrm{p}=0.024)$. In the per-protocol analysis, RR was $0.11(0.01-0.83)$ in patients aged $72 \mathrm{yr}$ or less, $0.61(0.32-1.17)$ in those over $72 \mathrm{yr}$, and $0.37(0.19-0.74, \mathrm{p}=0.0037)$ in the whole group after age-adjustment by stratification. The decrease in C-reactive protein levels was more pronounced in the MP group $(p=0.0003)$. Hyperglycemia was more frequent in the MP group.

Conclusions A short course of MP had a beneficial effect on the clinical outcome of severe COVID-19 pneumonia, decreasing the risk of the composite end point of admission to ICU, NIV or death. 
medRxiv preprint doi: https://doi.org/10.1101/2020.06.17.20133579; this version posted June 18, 2020. The copyright holder for this preprint (which was not certified by peer review) is the author/funder, who has granted medRxiv a license to display the preprint in perpetuity.

All rights reserved. No reuse allowed without permission.

\section{GLUCOGöID}

Open-label, pragmatic, partially randomized trial

\section{Methylprednisolone in adults hospitalized with COVID-19 pneumonia}

EudraCT number: 2020-001934-37

\section{Population \\ n: 90 (85 patients analyzed) \\ $58 \%$ male \\ Comparison
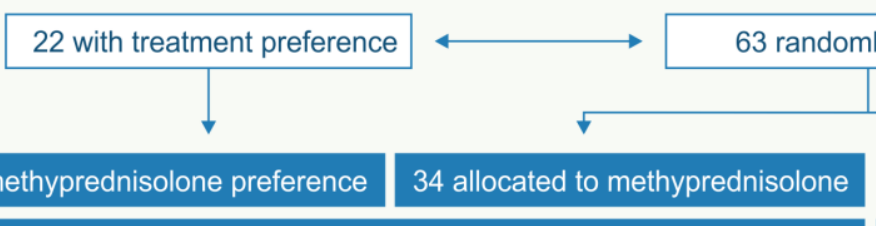 \\ 22 methyprednisolone preference \\ 34 allocated to methyprednisolone}

Age: $69 \mathrm{y} \pm 12$

Multicentre trial

56 on methyprednisolone

29 allocated to control

Primary composite outcome

- In-hospital all-cause mortality or

- Escalation to ICU admission or

- Progression of respiratory insufficiency that required NIV

Relative Risk $95 \%$ IC

\begin{tabular}{ll} 
All patients (Intention-to-treat) & $34 \%$ \\
$\leq 72$ y (Intention-to-treat) & $16 \%$ \\
$>72$ y (Intention-to-treat) & 48 \\
\hline All patients (per-protocol) & $\mathbf{2 4 \%}$
\end{tabular}

$0.70(0.41-1.18)$
$0.40(0.14-1.14)$
$0.66(0.66-1.11)$
$0.50(0.27-0.94)$

\section{$48 \%$}

$40 \%$

$67 \%$

$48 \%$ 
medRxiv preprint doi: https://doi.org/10.1101/2020.06.17.20133579; this version posted June 18, 2020. The copyright holder for this preprint (which was not certified by peer review) is the author/funder, who has granted medRxiv a license to display the preprint in perpetuity.

All rights reserved. No reuse allowed without permission.

\section{INTRODUCTION}

Since December 2019 the world faces a pandemic, coronavirus disease 2019 (COVID-19), caused by the novel Severe Acute Respiratory Syndrome Coronavirus 2 (ARS-CoV-2). The rapid spread and magnitude of COVID-19, along with the severity of the disease in some patients have stressed the whole world and have put into question our conceptions about viral respiratory infections.

The spectrum of COVID-19 ranges from asymptomatic patients or mild disease to severe progressive pneumonia, with multiple organ failure and death [1]. Patients with severe COVID-19 develop, usually after a first stage with mild manifestations, a disorder similar to acute respiratory distress syndrome (ARDS). These patients suffer a hyper-inflammatory syndrome characterised by a rapid hypercytokinemia targeting the lung parenchyma and/or vasculature [2][3]. This cytokine storm-like state is characterised by increased interleukins (IL) and acute phase reactants [4]. Recent retrospective studies confirmed the association of elevated ferritin, lactate dehydrogenase or IL-6 with poor prognosis [5], thus suggesting that mortality may be related to virally-driven hyper-inflammation. Hence, in this phase, the use of immunomodulators may be justified.

From previous coronavirus outbreaks, such as Severe Acute Respiratory Syndrome (SARS) and Middle East Respiratory Syndrome (MERS), as well as from other viral pneumonias, we learned that corticosteroid therapy should not be routinely recommended, for they might exacerbate lung injury and even increase mortality [6]. Thus, current interim guidance from the World Health Organization (WHO) advises against corticosteroid use in Covid-19 patients unless indicated for another reason [7].

However, the rapid progression of severe cases of SARS-CoV-2 infection, along with the marked increase in several laboratory biomarkers of systemic inflammatory response and the absence of effective antiviral therapy, has led clinicians to question the recommendation against using corticosteroids. Besides, the potential benefit of corticosteroids in ARDS of other causes prompted interest in using them in COVID-19 patients [8]. Thus, corticosteroids and other immunomodulators are now frequently used in severe COVID-19 cases $[9,10]$ and have gained support from some scientific societies under certain 
medRxiv preprint doi: https://doi.org/10.1101/2020.06.17.20133579; this version posted June 18, 2020. The copyright holder for this preprint (which was not certified by peer review) is the author/funder, who has granted medRxiv a license to display the preprint in perpetuity.

All rights reserved. No reuse allowed without permission.

circumstances [11,12]. Recommendations to prescribe corticosteroids are based on anecdotal observations and retrospective uncontrolled series of patients, but so far no controlled prospective trials are available [13-16]. For instance, a multicentre study comparing two periods of COVID-19 attendance with or without steroids showed a beneficial effect of the early use of corticosteroids [16]. Interestingly, a composite end-point (escalation of care from the hospitalization ward to the intensive care unit (ICU), new requirement for mechanical ventilation, or mortality) occurred in $54 \%$ of patients who received standard therapy, and in $35 \%$ of those treated with corticosteroids $(p=0.005)$. In a retrospective study of 201 patients, methylprednisolone (MP) was associated with reduced mortality in patients with ARDS [14]. In another retrospective study, $11 \%$ of patients on MP and $35 \%$ patients without corticosteroids required mechanical ventilation $(p=0.05)$ [17]. On the contrary, some studies argued that corticosteroids may be deleterious and cause a delayed viral clearance in COVID-19 [18], as it was also found in SARS [19].

Up to $5-10 \%$ of the hospitalized patients with COVID-19 develop ARDS and require respiratory support in ICU [20]. Lacking a drug specifically designed for this novel coronavirus and with the prospect of several months or even years until the development of an effective vaccine, we urgently need some drug repositioning for the treatment of COVID-19. These considerations motivated us to design and conduct a pragmatic, randomized, controlled trial (GLUCOCOVID) to explore the role of a short course of MP in patients with COVID-19 pneumonia at risk of developing respiratory failure and ARDS. Here we report a planned interim analysis of the first 90 patients included.

\section{METHODS}

\section{Study design}

GLUCOCOVID is a partially randomized preference, open-label, controlled, two-arm, parallel-group, trial conducted at 5 hospitals in Spain in April-May 2020. The study was designed to address the efficacy of adding corticosteroids to standard therapy in patients with moderate-severe COVID-19.

We designed a pragmatic, partially randomized trial, including a clinician's preference arm in an attempt to avoid inclusion bias in the current setting in which many physicians feel glucocorticoids may have a 
medRxiv preprint doi: https://doi.org/10.1101/2020.06.17.20133579; this version posted June 18, 2020. The copyright holder for this preprint (which was not certified by peer review) is the author/funder, who has granted medRxiv a license to display the preprint in perpetuity.

All rights reserved. No reuse allowed without permission.

beneficial effect in COVID-19 despite the absence of controlled clinical trials. This approach is based upon the well-described preference trial designs, which allow incorporating individual's preferences and questions about equipoise $[21,22]$. The principal investigator of every hospital encouraged the medical team to maximize the number of patients included by the randomization way, but all included patients were analysed regardless they were randomized or not [23]. The study was registered at the European Clinical Trials Register (EudraCT number: 2020-001934-37) and the Spanish Registry of Clinical Studies (2020-001934-37).

\section{Participants}

Eligible patients were hospitalized subjects over 18 years of age, with a laboratory confirmed diagnosis of SARS-CoV2 infection. Additional inclusion criteria were all the following:

1) Symptom duration of at least 7 days

2) Radiological evidence of lung disease in chest X-ray or CT-scan

3) Moderate-to-severe disease with abnormal gas exchange: $\mathrm{PaFi}(\mathrm{PaO} 2 / \mathrm{FiO} 2)<300$, or SAFI (SAO2/FiO2) $<400$, or at least 2 criteria of the BRESCIA-COVID Respiratory Severity Scale (BCRSS) [24].

4) Laboratory parameters suggesting a hyper-inflammatory state: serum C-Reactive Protein (CRP) $>15 \mathrm{mg} / \mathrm{dl}$, D-dimer $>800 \mathrm{mg} / \mathrm{dl}$, ferritin $>1000 \mathrm{mg} / \mathrm{dl}$ or IL-6 levels $>20 \mathrm{pg} / \mathrm{ml}$.

Patients were excluded if they were intubated or mechanically ventilated, were hospitalized in the ICU, were treated with corticosteroids or immunosuppressive drugs at the time of enrollment, have chronic kidney disease on dialysis, were pregnant or refused to participate.

The study was approved by the Institutional Review Boards of participating hospitals, and patients gave informed consent.

\section{Treatment allocation}

Once an eligible patient was identified, if the clinical team decided that a strong preference for glucocorticoid therapy existed, the patient was allocated to the preference arm. Otherwise, the patient 
medRxiv preprint doi: https://doi.org/10.1101/2020.06.17.20133579; this version posted June 18, 2020. The copyright holder for this preprint (which was not certified by peer review) is the author/funder, who has granted medRxiv a license to display the preprint in perpetuity.

All rights reserved. No reuse allowed without permission.

was randomized (1:1) and allocated to the MP or control arm accordingly. Patients were randomized based on a spreadsheet that transformed every medical record number into a group allocation.

\section{Interventions}

Patients in both study groups received standard of care (SOC) therapy according to the local protocols. SOC protocols were similar across the participating hospitals and were based on the Spanish Ministry of Health, Consumer Affairs and Social Welfare technical documents [25] and WHO recommendations [7]. SOC included symptomatic treatment with acetaminophen, oxygen therapy, thrombosis prophylaxis with low molecular weight heparin, and antibiotics for co-infections. Azythromycin, hydroxychloroquine and lopinavir plus ritonavir were frequently prescribed.

Biochemical tests and image studies were performed according to clinical criteria and local protocols, using standard techniques.

In addition to SOC, patients in the experimental group received methylprednisolone (MP) $40 \mathrm{mg}$ intravenously every 12 hours for 3 days and then $20 \mathrm{mg}$ every 12 hours for 3 days. The clinical teams freely prescribed Interleukin-blocking agents and other therapies, as indicated.

\section{Outcome}

The primary outcome measure was a composite endpoint that included in-hospital all-cause mortality, escalation to ICU admission, or progression of respiratory insufficiency that required non-invasive ventilation (NIV).

The secondary outcomes were the effects on the individual components of the composite endpoint and laboratory biomarkers at baseline and 6 days after inclusion (time window 4-8 days).

\section{Sample size and Statistical analysis}

The initial sample size target was estimated assuming that MP could reduce the primary composite endpoint by $50 \%$ or more. With an event rate of $40 \%$ in the control arm, 90 patients in each study arm would be needed. Here we report the results of the interim analysis, which was planned a priori after 
medRxiv preprint doi: https://doi.org/10.1101/2020.06.17.20133579; this version posted June 18, 2020. The copyright holder for this preprint (which was not certified by peer review) is the author/funder, who has granted medRxiv a license to display the preprint in perpetuity.

All rights reserved. No reuse allowed without permission.

inclusion of one-half of the patients, to avoid delaying the communication of clinically useful data in the current pandemic scenario.

Continuous variables were compared using Student t-test and ANOVA, or Mann-Whitney $U$ test and Kruskal-Wallis test if not normally distributed. We compared categorical variables using Fisher's exact test. Relative risk ratio and differences in absolute risks were derived from the estimated risks of the primary composite endpoint. In stratified analyses, the combined risk ratio was computed with the Mantel-Haenszel method. Multivariate-adjusted risk ratio was estimated by using unconditional logistic regression. Survival plots were built with the Kaplan-Meier method and compared with the log-rank test. Patients were censored at hospital discharge or day 15 after inclusion.

The analyses were performed according to both intention-to-treat and per-protocol principles. For the latter, we considered those patients in the MP group who had received at least 3 doses of the drug (thus elapsing at least $24 \mathrm{hr}$ from inclusion) before the primary endpoint occurred. The treatment arms were studied considering independently the preference and randomization arms, as well as combining both MP arms.

\section{RESULTS}

Five out of 90 patients initially included were later excluded from the analysis ( 2 were previously on corticosteroids, 1 was on NIV, 1 was taken to ICU simultaneously to MP onset, and 1 patient with initial suspicion of COVID-19 was finally diagnosed of vasculitis). Thus, 85 patients were analyzed; 22 received MP according to the clinician's preference, and 63 were randomized. Although allowed by design, no patient was included in the control arm by clinician's preference. In 3 patients of the control group, but none in the MP group, clinicians prescribed MP boluses after initial allocation because of deterioration of the patient's condition. The baseline characteristics of the patients are shown in table 1 . Those in the MP arm were slightly older, but the baseline characteristics were otherwise very similar across groups. Therefore, we combined the preferential and randomized arms of MP for further analysis (figure 1). The use of lopinavir/ritonavir was slightly more frequent in the control arm. More than $90 \%$ of the patients 
medRxiv preprint doi: https://doi.org/10.1101/2020.06.17.20133579; this version posted June 18, 2020. The copyright holder for this preprint (which was not certified by peer review) is the author/funder, who has granted medRxiv a license to display the preprint in perpetuity.

All rights reserved. No reuse allowed without permission.

took hydroxichloroquine and/or azithromycin during hospital admission. Although the active search for arrhythmias was not planned in the study protocol, no clinically significant arrhythmias were reported.

In the intention-to-treat analysis, all patients who received at least one dose of MP were included in the treatment arm. In this univariate analysis, age and baseline SAFI and CRP levels were the only variables significantly associated with the primary composite endpoint (admission to ICU, NIV, or death). Mean age was $67 \pm 11$ and $72 \pm 13 \mathrm{yr}$ in patients with a good and a bad outcome, respectively $(p=0.07)$; mean SAFI was $327 \pm 93$ and $218 \pm 86$, respectively $(p<0.001)$; and mean CRP was $14.3 \pm 8.3$ and $18.8 \pm 8.0$, respectively $(p=0.016)$. In line with the influence of patients' age on disease severity, subjects above the median age of $72 \mathrm{yr}$ were more likely to reach the composite endpoint than those aged $72 \mathrm{yr}$ or less (relative risk 1.97, $95 \% \mathrm{Cl} 1.11-3.47, \mathrm{p}=0.025)$. The primary composite endpoint occurred somewhat less frequently in the MP group. Although the difference was not statistically significant in the unadjusted analysis, in the agestratified analysis, MP was associated with a significantly lower risk of bad outcome, with a $45 \%$ relative risk reduction and $24 \%$ absolute risk reduction (table 2 ). Thus, age was a confounding variable, but there was no statistically significant interaction between age and the effect of MP.

At baseline, all study groups had similar biomarker levels. Six days later, CRP levels were lower in both groups, but the decrease was more pronounced in the MP group $(p=0.0003)$. Other biomarkers were similar in the control and MP groups (figure 2).

Fifteen patients received the IL-6 blocking agent tocilizumab (10 [18\%] in the MP group and 4 [14\%] in the control group); in 7 patients of the MP group (12\%), the IL-1 blocking agent anakinra was prescribed. After patients treated with tocilizumab and/or anakinra were excluded from the analysis, the results were similar to those found in the whole group: MP-treated patients had a lower risk of reaching the combined endpoint (Relative risk reduction 55\%; 95\% $\mathrm{Cl} 15-76 \%$; $p=0.015$ ).

No major side effects were observed, but hyperglycemia (>180 mg/dl) was more frequent in the MP group. Twelve patients on MP (21\%), and none in the control group developed hyperglycemia $>180 \mathrm{mg} / \mathrm{dl}$ $(p=0.006)$. 
medRxiv preprint doi: https://doi.org/10.1101/2020.06.17.20133579; this version posted June 18, 2020. The copyright holder for this preprint (which was not certified by peer review) is the author/funder, who has granted medRxiv a license to display the preprint in perpetuity.

All rights reserved. No reuse allowed without permission.

In the per-protocol analysis, we included 78 patients who received at least 3 doses of MP before the composite endpoint occurred (this is, at least 24 hours elapsed between inclusion and the occurrence of an endpoint event). As shown in table 3, MP was associated with a 50\% lower risk of an adverse outcome, in the overall analysis, and a $63 \%$ relative reduction of adverse outcome risk in the age-stratified analysis. In the multivariate analysis, adjusting by age and baseline SAFI, patients on MP had a relative risk of 0.28 (95\% $\mathrm{Cl} 0.08-0.80, \mathrm{p}=0.013)$. Regarding the individual components of the main outcome variable, patients on MP had a significantly lower risk of ICU admission ( $8 \%$ vs $28 \%, p=0.047$ ), with similar frequency of NIV ( $6 \%$ vs $10 \%$, ns) and death ( $20 \%$ vs $18 \%$, ns) (supplementary table). Similarly, when the analysis was limited to the randomized arms, the risk of adverse outcome, as defined by the composite endpoint, was significantly lower in the MP group than in the control group, with an adjusted risk ratio (adjusted by age and baseline SAFI) of 0.28 (95\% $\mathrm{Cl} 0.07-0.90, \mathrm{p}=0.029)$.

Survival analysis confirmed the influence of age and treatment. Patients on MP had a significantly higher chance of good outcome ( $p=0.001$ by log-rank test) (figure 3 ). Similar results were observed when patients assigned to MP by clinician's preference and those randomized to MP were considered separately. Pairwise-comparisons revealed significant differences between control and MP groups, but not between both MP groups (control-randomized MP, $p=0.019$; control-preference MP, $p=0.003$; randomized MPpreference MP, $\mathrm{p}=0.233$; supplementary figure).

\section{DISCUSSION}

COVID-19 has put the whole world under unprecedented stress. Thus, clinicians have been forced to take decisions in the absence of solid evidence about diagnosis and therapy. However, an impressive amount of information has been gathered in a few weeks, which has led to deeper disease knowledge and better patient management. For example, from the initial conception of COVID-19 as a pure infectious disease, accumulated data have helped to understand the important role of the host inflammatory response. In this line, uncontrolled observations have suggested a beneficial effect of anti-inflammatory therapy, including IL-blocking agents and glucocorticoids $[16,26,27]$. The latter are particularly appealing because 
medRxiv preprint doi: https://doi.org/10.1101/2020.06.17.20133579; this version posted June 18, 2020. The copyright holder for this preprint (which was not certified by peer review) is the author/funder, who has granted medRxiv a license to display the preprint in perpetuity.

All rights reserved. No reuse allowed without permission.

they are inexpensive, widely available, and easy to administer. However, the role of corticosteroids in viral-induced and other forms of ARDS is controversial [19].

Our study was motivated by this controversy. Since many clinicians in our hospitals had a positive feeling about the effect of glucocorticoids in patients with severe COVID-19, a purely randomized design appeared difficult to follow, and it could likely had implied a high risk of inclusion bias. So, we adopted a pragmatic mixed preference/randomized design. Although this design may complicate the analysis, the three arms showed similar baseline characteristics (except for some differences in patients' age). In fact, patients in the MP arm were somewhat older than those in the control arm. This is an important issue, for in this study we confirmed that advanced age is a risk factor for poor outcome, in line with previously reported series $[14,28-30]$. The confounding effect of age is complex, as it may influence not only the course of the disease, but also decisions about escalation to ICU admission in a scenario of limited resources.

Interestingly, in this trial MP administration was associated with a reduced risk of poor outcome, which was statistically significant after adjustment for confounding factors, such as age and baseline respiratory status (as assessed by SAFI). Our results are consistent with those of a recent quasi-experimental study [16] that used similar endpoints and MP doses. The primary composite endpoint occurred in $54 \%$ patients in the SOC group and in $35 \%$ in the early glucocorticoids group. Those figures are remarkably similar to ours ( $48 \%$ vs $34 \%)$.

Our study has several limitations. Firstly, the small sample size. Indeed, it is a pre-planned interim analysis of an ongoing trial, not powered to explore the association of treatment with individual endpoints. However, we feel the results are important to inform clinical decisions while ongoing larger controlled randomized trials are completed. Secondly, the inclusion of a preferential arm theoretically hampers the balance of baseline characteristics across study arms. Nevertheless, actual differences were not large, as shown in table 1. In fact, the beneficial effect of MP was observed not only in the analysis combining the randomized and preferential arms, but also when only the randomized arms were compared, reinforcing the conclusions of the study. Third, there might be differences in patient management across the 
medRxiv preprint doi: https://doi.org/10.1101/2020.06.17.20133579; this version posted June 18, 2020. The copyright holder for this preprint (which was not certified by peer review) is the author/funder, who has granted medRxiv a license to display the preprint in perpetuity.

All rights reserved. No reuse allowed without permission.

participating hospitals. Fortunately, in practice, the protocols for COVID-19 were very similar, because they were based on the recommendations of the Spanish Ministry of Health, including the use of azithromycin, hydroxychloroquine, and lopinavir/ritonavir. Fourth, due to the rapidly deteriorating course of some COVID-19 cases, they escalated to ICU or NIV within the first 24 hours of inclusion in the study. Therefore, they received only 1-2 doses of MP, thus impeding to assess the effect of the drug. We included a per-protocol analysis excluding those patients to avoid their confounding effect.

Our study shows that MP improves the prognosis of COVID-19. Elucidating its precise role within a treatment strategy would need further studies, but our data suggest that MP is useful in patients with moderate/severe disease with evidence of inflammatory activation. However, several patients in our cohort deteriorated rapidly and required escalation of therapy. Thus, it would be interesting to initiate studies to explore the role of glucocorticoids at somewhat earlier stages of disease.

In conclusion, the interim analysis of this ongoing clinical trial shows a beneficial effect of a short course of methylprednisolone on the clinical outcome of patients with severe COVID-19. Our data suggest that corticosteroids may have a clinically important effect in reducing the risk of developing severe respiratory insufficiency and ARDS. 
medRxiv preprint doi: https://doi.org/10.1101/2020.06.17.20133579; this version posted June 18, 2020. The copyright holder for this preprint (which was not certified by peer review) is the author/funder, who has granted medRxiv a license to display the preprint in perpetuity.

All rights reserved. No reuse allowed without permission.

Funding: The authors received no specific funding for this work.

Conflict of interest: The authors declare that they have no conflicting interests.

Acknowledgments: We thank Prof. Jose Luis Pérez-Castrillón (Universidad de Valladolid) for useful discussion and comments on the manuscript, and Dr. Mar García Saiz (Hospital UM Valdecilla) for helping with trial registry.

This trial would have been impossible without the support and collaboration of the hundreds of health professionals involved in the care of COVID-19 patients in our hospitals during the 2020 Spring pandemic.

\section{Author roles}

Conceptualization: LC-G, JLH, MCF, JAR

Data collection: All authors

Data analysis: LC-G, JAR

Manuscript draft: LC-G, MCF, JMO, JMC, FA, VM, AB, JAR

Critical input and final manuscript approval: All authors

Project supervision: LC-G, JAR

JAR has full access to the data and is the guarantor for the data 
medRxiv preprint doi: https://doi.org/10.1101/2020.06.17.20133579; this version posted June 18, 2020. The copyright holder for this preprint (which was not certified by peer review) is the author/funder, who has granted medRxiv a license to display the preprint in perpetuity.

All rights reserved. No reuse allowed without permission.

\section{References}

1. Guan W-J, Ni Z-Y, Hu Y, et al. Clinical Characteristics of Coronavirus Disease 2019 in China. N Engl J Med 2020; 382:1708-1720.

2. Mehta $P$, McAuley DF, Brown M, et al. COVID-19: consider cytokine storm syndromes and immunosuppression. Lancet 2020; 395:1033-1034.

3. Siddiqi H, Mehra M. COVID-19 Illness in Native and Immunosuppresed States: A clinicaltherapeutic staging proposal. J heart lung transplant 2020; 39:405-407.

4. McGonagle D, Sharif K, O'Regan A, Bridgewood C. The Role of Cytokines Including Interleukin-6 in COVID-19 Induced Pneumonia and Macrophage Activation Syndrome-Like Disease. Autoimmun Rev 2020; 19:102537.

5. Zhou F, Yu T, Du R, et al. Clinical course and risk factors for mortality of adult inpatients with COVID-19 in Wuhan, China: a retrospective cohort study. Lancet 2020; 395:1054-1062.

6. Russell CD, Millar JE, Baillie JK. Clinical evidence does not support corticosteroid treatment for 2019-nCoV lung injury. Lancet 2020; 395:473-475.

7. Clinical management of severe acute respiratory infection when COVID-19 is suspected. Available at: https://www.who.int/publications-detail/clinical-management-of-severe-acute-respiratoryinfection-when-novel-coronavirus-(ncov)-infection-is-suspected. Accessed 2 April 2020.

8. Villar J, Ferrando C, Martínez D, et al. Dexamethasone treatment for the acute respiratory distress syndrome: a multicentre, randomised controlled trial. Lancet Respir Med 2020; 8:267-276.

9. Shang L, Zhao J, Hu Y, Du R, Cao B. On the use of corticosteroids for 2019-nCoV pneumonia. Lancet 2020; 395:683-684.

10. Treatment - Covid Reference. Available at: https://covidreference.com/treatment. Accessed 10 May 2020.

11. Zhao JP, Hu Y, Du RH, et al. [Expert consensus on the use of corticosteroid in patients with 2019nCoV pneumonia]. Zhonghua Jie He He Hu Xi Za Zhi 2020; 43:183-184.

12. Alhazzani W, Møller MH, Arabi YM, et al. Surviving Sepsis Campaign: guidelines on the management of critically ill adults with Coronavirus Disease 2019 (COVID-19). Intensive Care Med 2020;

13. Zhou W, Liu Y, Tian D, et al. Potential benefits of precise corticosteroids therapy for severe 2019nCoV pneumonia. Signal Transduct Target Ther 2020; 5:18.

14. Wu C, Chen X, Cai Y, et al. Risk Factors Associated With Acute Respiratory Distress Syndrome and Death in Patients With Coronavirus Disease 2019 Pneumonia in Wuhan, China. JAMA Intern Med 2020; :e200994.

15. Zha L, Li S, Pan L, et al. Corticosteroid treatment of patients with coronavirus disease 2019 (COVID19). Med J Aust 2020; 212:416-420.

16. Fadel R, Morrison AR, Vahia A, et al. Early Short Course Corticosteroids in Hospitalized Patients with COVID-19. Clin Infect Dis 2020; 
medRxiv preprint doi: https://doi.org/10.1101/2020.06.17.20133579; this version posted June 18, 2020. The copyright holder for this preprint (which was not certified by peer review) is the author/funder, who has granted medRxiv a license to display the preprint in perpetuity.

All rights reserved. No reuse allowed without permission.

17. Wang D, Hu B, Hu C, et al. Clinical Characteristics of 138 Hospitalized Patients With 2019 Novel Coronavirus-Infected Pneumonia in Wuhan, China. JAMA 2020; 323:1061-1069.

18. Ling $\mathrm{Y}, \mathrm{X}$ U S-B, Lin Y-X, et al. Persistence and clearance of viral RNA in 2019 novel coronavirus disease rehabilitation patients. Chin Med J 2020; 133:1039-1043.

19. Stockman LJ, Bellamy R, Garner P. SARS: systematic review of treatment effects. PLoS Med 2006; 3:e343.

20. Yang $X, Y u Y, X u J$, et al. Clinical course and outcomes of critically ill patients with SARS-CoV-2 pneumonia in Wuhan, China: a single-centered, retrospective, observational study. Lancet Respir Med 2020; 8:475-481.

21. Wasmann KA, Wijsman P, van Dieren S, Bemelman W, Buskens C. Partially randomised patient preference trials as an alternative design to randomised controlled trials: systematic review and meta-analyses. BMJ Open 2019; 9:e031151.

22. Kowalski CJ. When ethics precludes randomization: put prospective, matched-pair observational studies to work. Perspect Biol Med 2013; 56:184-197.

23. Hernán MA, Robins JM. Per-Protocol Analyses of Pragmatic Trials. N Engl J Med 2017; 377:13911398.

24. Brescia-COVID Respiratory Severity Scale (BCRSS)/Algorithm. Available at:

https://www.mdcalc.com/brescia-covid-respiratory-severity-scale-bcrss-algorithm. Accessed 13 April 2020.

25. Tratamientos disponibles para el manejo de la infección respiratoria por SARS-CoV-2. Agencia Española de Medicamentos y Productos Sanitarios. Available at: https://www.aemps.gob.es/laaemps/ultima-informacion-de-la-aemps-acerca-del-covid\%e2\%80\%9119/tratamientosdisponibles-para-el-manejo-de-la-infeccion-respiratoria-por-sars-cov-2/. Accessed 15 April 2020.

26. Alzghari SK, Acuña VS. Supportive Treatment with Tocilizumab for COVID-19: A Systematic Review. J Clin Virol 2020; 127:104380.

27. Salvi R, Patankar P. Emerging pharmacotherapies for COVID-19. Biomed Pharmacother 2020; :110267.

28. Wynants L, Van Calster B, Bonten MMJ, et al. Prediction models for diagnosis and prognosis of covid-19 infection: systematic review and critical appraisal. BMJ 2020; 369:m1328.

29. Jordan RE, Adab P, Cheng KK. Covid-19: risk factors for severe disease and death. BMJ 2020; 368:m1198.

30. Grasselli G, Zangrillo A, Zanella A, et al. Baseline Characteristics and Outcomes of 1591 Patients Infected With SARS-CoV-2 Admitted to ICUs of the Lombardy Region, Italy. JAMA 2020; 323:15741581. 
medRxiv preprint doi: https://doi.org/10.1101/2020.06.17.20133579; this version posted June 18, 2020. The copyright holder for this preprint (which was not certified by peer review) is the author/funder, who has granted medRxiv a license to display the preprint in perpetuity.

All rights reserved. No reuse allowed without permission.

Table 1. Baseline characteristics of the study groups, Mean and SD for continuous variables, and number and percentage for categorical variables.

\begin{tabular}{|c|c|c|c|c|c|}
\hline & $\begin{array}{l}\text { Total } \\
(n=85)\end{array}$ & $\begin{array}{l}\text { Preference arm } \\
\text { (methyl- } \\
\text { prednisolone) } \\
(n=22)\end{array}$ & $\begin{array}{l}\text { Control arm } \\
\qquad(n=29)\end{array}$ & $\begin{array}{c}\text { Methyl- } \\
\text { prednisolone } \\
\text { arm } \\
(n=34)\end{array}$ & $p$ \\
\hline Age, yr & $69 \pm 12$ & $66 \pm 13$ & $66 \pm 12$ & $73 \pm 11$ & 0.03 \\
\hline Sex (male, \%) & $49(58)$ & $10(45)$ & $16(55)$ & $23(68)$ & $>0.10$ \\
\hline \multicolumn{6}{|l|}{ COVID-19 characteristics } \\
\hline - SAFI (SaO2/FI O2) & $285 \pm 105$ & $323 \pm 78$ & $281 \pm 121$ & $264 \pm 101$ & $>0.10$ \\
\hline - Creatinine, $\mathrm{mg} / \mathrm{dl}$ & $0.9 \pm 0.4$ & $1.0 \pm 0.4$ & $0.9 \pm 0.4$ & $0.8 \pm 0.3$ & 0.10 \\
\hline 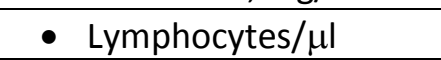 & $872 \pm 760$ & $752 \pm 21$ & $814 \pm 305$ & $997 \pm 1125^{*}$ & $>0.10$ \\
\hline - Platelets / $\mu \mathrm{l}$ & $\begin{array}{c}293764 \pm \\
353413\end{array}$ & $\begin{array}{c}255681 \pm \\
135722\end{array}$ & $\begin{array}{c}269827 \pm \\
96344\end{array}$ & $\begin{array}{c}261205 \pm \\
139107\end{array}$ & $>0.10$ \\
\hline - $\mathrm{CRP}, \mathrm{mg} / \mathrm{dl}$ & $16.1 \pm 8.4$ & $12.8 \pm 8.4$ & $17.2 \pm 8.8$ & $17.1 \pm 7.8$ & $>0.08$ \\
\hline - D Dimer, mg/dl & $2308 \pm 5395$ & $2310 \pm 3638$ & $1297 \pm 982$ & $3163 \pm 7902$ & $>0.10$ \\
\hline - Ferritin, mg/dl & $1129 \pm 905$ & $992 \pm 945$ & $1078 \pm 882$ & $1259 \pm 907$ & $>0.10$ \\
\hline \multicolumn{6}{|l|}{ Comorbidities } \\
\hline - Hypertension, n (\%) & $39(46)$ & $9(41)$ & $12(41)$ & $18(53)$ & $>0.10$ \\
\hline - Cardiac disease, n (\%) & $9(11)$ & $1(5)$ & $4(14)$ & $4(12)$ & $>0.10$ \\
\hline $\begin{array}{l}\text { - Respiratory disease, } \mathrm{n} \\
\text { (\%) }\end{array}$ & $7(8)$ & $2(9)$ & $1(3)$ & $4(12)$ & $>0.10$ \\
\hline - Diabetes, n (\%) & $13(15)$ & $2(9)$ & $4(14)$ & $7(21)$ & $>0.10$ \\
\hline \multicolumn{6}{|l|}{ Therapy } \\
\hline - Azithromycin, n (\%) & $76(89)$ & $18(81)$ & $29(100)$ & $29(85)$ & 0.07 \\
\hline $\begin{array}{l}\text { - Hydroxychloroquine, } \\
\mathrm{n}(\%)\end{array}$ & $81(95)$ & $20(91)$ & $29(100)$ & $32(94)$ & $>0.10$ \\
\hline $\begin{array}{l}\text { - Lopinavir/Ritonavir, } \mathrm{n} \\
(\%)\end{array}$ & $67(79)$ & $14(63)$ & $28(97)$ & $25(74)$ & 0.01 \\
\hline
\end{tabular}

- Included 1 patient with CLL 
medRxiv preprint doi: https://doi.org/10.1101/2020.06.17.20133579; this version posted June 18, 2020. The copyright holder for this preprint (which was not certified by peer review) is the author/funder, who has granted medRxiv a license to display the preprint in perpetuity.

All rights reserved. No reuse allowed without permission.

Table 2. Intention-to-treat analysis. Comparison of patients in the control and methylprednisolone (MP) arms. Unstratified and age-stratified analyses.

\begin{tabular}{|c|c|c|c|c|}
\hline & $\begin{array}{c}\text { Adverse } \\
\text { outcome* }\end{array}$ & $\begin{array}{c}\text { Good } \\
\text { outcome }\end{array}$ & $\begin{array}{c}\text { Relative } \\
\text { Risk }\end{array}$ & $\mathbf{p}$ \\
\hline \multicolumn{5}{|l|}{ All patients } \\
\hline Control & $14(48)$ & $15(52)$ & 1 & \\
\hline $\mathrm{MP}$ & $19(34)$ & $37(66)$ & $\begin{array}{c}0.70 \\
(0.41-1.18) \\
\end{array}$ & 0.25 \\
\hline \multicolumn{5}{|l|}{ Age $\leq 72$} \\
\hline Control & $8(40)$ & $12(60)$ & 1 & \\
\hline $\mathrm{MP}$ & $4(16)$ & $21(84)$ & $\begin{array}{c}0.40 \\
(0.14-1.14)\end{array}$ & \\
\hline \multicolumn{5}{|l|}{ Age $>72$} \\
\hline Control & $6(67)$ & $3(33)$ & 1 & \\
\hline MP & $15(48)$ & $16(52)$ & $\begin{array}{c}0.66 \\
(0.40-1.11) \\
\end{array}$ & \\
\hline Combined (MH) & & & $\begin{array}{c}0.55 \\
(0.33-0.91)\end{array}$ & 0.025 \\
\hline
\end{tabular}

*Primary composite outcome (ICU admission, NIV or death)

MP: methylprednisolone. MH: Mantel-Haenszel 
medRxiv preprint doi: https://doi.org/10.1101/2020.06.17.20133579; this version posted June 18, 2020. The copyright holder for this preprint (which was not certified by peer review) is the author/funder, who has granted medRxiv a license to display the preprint in perpetuity.

All rights reserved. No reuse allowed without permission.

Table 3. Per protocol analysis after excluding 7 patients who received only 1-2 doses of methylprednisolone.

\begin{tabular}{|c|c|c|c|c|}
\hline & $\begin{array}{c}\text { Adverse } \\
\text { outcome* }\end{array}$ & $\begin{array}{c}\text { Good } \\
\text { outcome }\end{array}$ & $\begin{array}{c}\text { Relative } \\
\text { Risk }\end{array}$ & $\mathbf{P}$ \\
\hline \multicolumn{5}{|l|}{ All patients } \\
\hline Control & $14(48)$ & $15(52)$ & 1 & \\
\hline $\mathrm{MP}$ & $12(24)$ & $37(76)$ & $\begin{array}{c}0.50 \\
(0.27-0.94) \\
\end{array}$ & 0.046 \\
\hline \multicolumn{5}{|l|}{ Age $\leq 72$} \\
\hline Control & $8(40)$ & $12(60)$ & 1 & \\
\hline $\mathrm{MP}$ & $1(4)$ & $21(96)$ & $\begin{array}{c}0.11 \\
(0.01-0.83)\end{array}$ & \\
\hline \multicolumn{5}{|l|}{ Age $>72$} \\
\hline Control & $6(67)$ & $3(33)$ & 1 & \\
\hline $\mathrm{MP}$ & $11(41)$ & $16(59)$ & $\begin{array}{c}0.61 \\
(0.32-1.17) \\
\end{array}$ & \\
\hline Combined (MH) & & & $\begin{array}{c}0.37 \\
(0.19-0.74)\end{array}$ & 0.0037 \\
\hline
\end{tabular}

*Primary composite outcome (ICU admission, NIV or death)

MP: methylprednisolone. MH: Mantel-Haenszel 
medRxiv preprint doi: https://doi.org/10.1101/2020.06.17.20133579; this version posted June 18, 2020. The copyright holder for this preprint (which was not certified by peer review) is the author/funder, who has granted medRxiv a license to display the preprint in perpetuity.

All rights reserved. No reuse allowed without permission.

\section{Figure legends}

Figure 1. GLUCOCOVID flow diagram

Figure 2. Biomarkers of control and MP groups at baseline (Pre) and 6 days (range 4-8) after inclusion. Mean and 2xSEM.

Figure 3. Kaplan-Meier plots showing the probability of not occurring the primary composite endpoint (ICU admission, need of NIV or death) of the control (grey) and MP (red) groups in COVID-19 patients stratified by age. 
medRxiv preprint doi: https://doi.org/10.1101/2020.06.17.20133579; this version posted June 18, 2020. The copyright holder for this preprint (which was not certified by peer review) is the author/funder, who has granted medRxiv a license to display the preprint in perpetuity.

All rights reserved. No reuse allowed without permission.

Figure 1

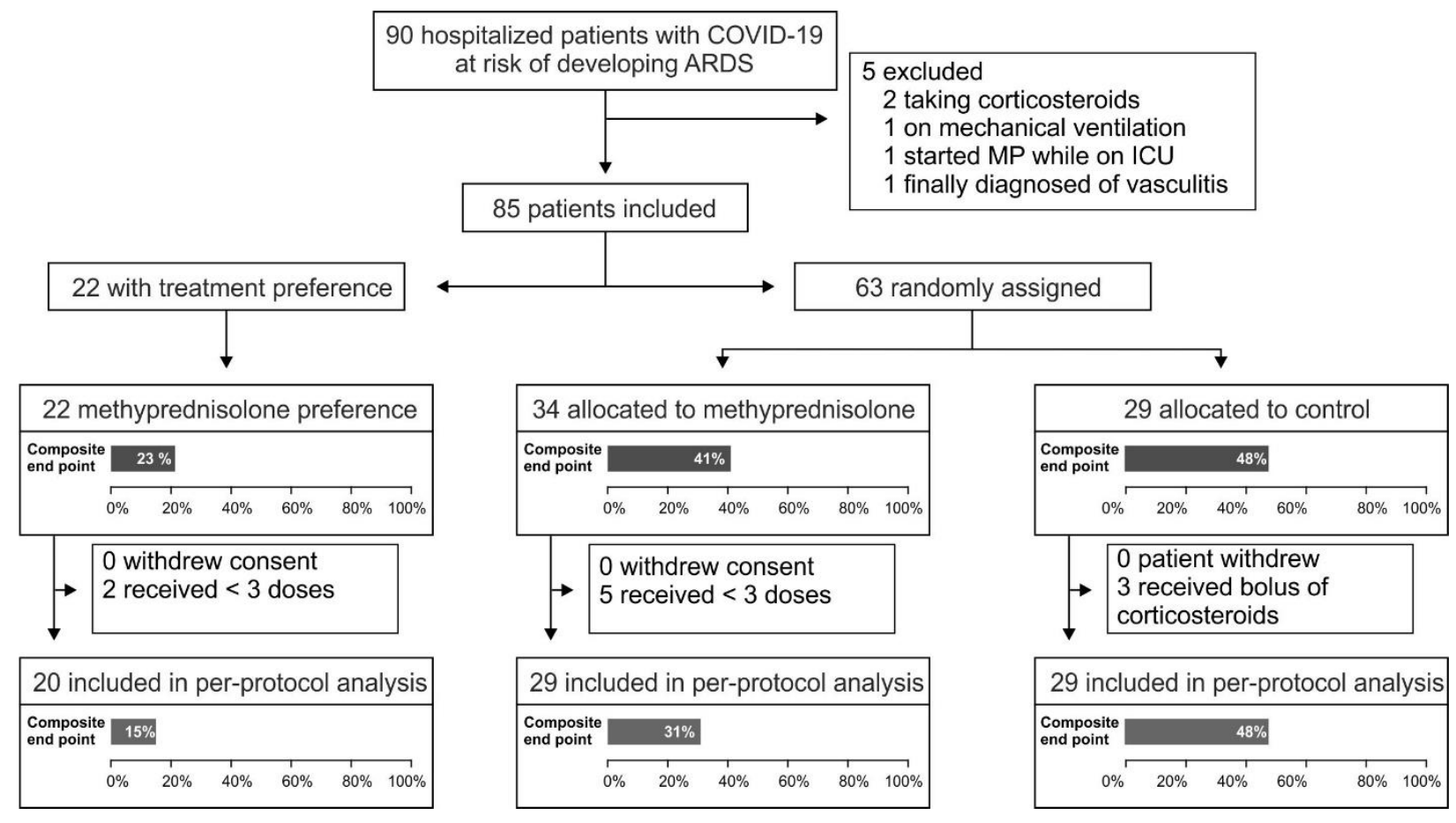


medRxiv preprint doi: https://doi.org/10.1101/2020.06.17.20133579; this version posted June 18, 2020. The copyright holder for this preprint (which was not certified by peer review) is the author/funder, who has granted medRxiv a license to display the preprint in perpetuity.

All rights reserved. No reuse allowed without permission.

Figure 2
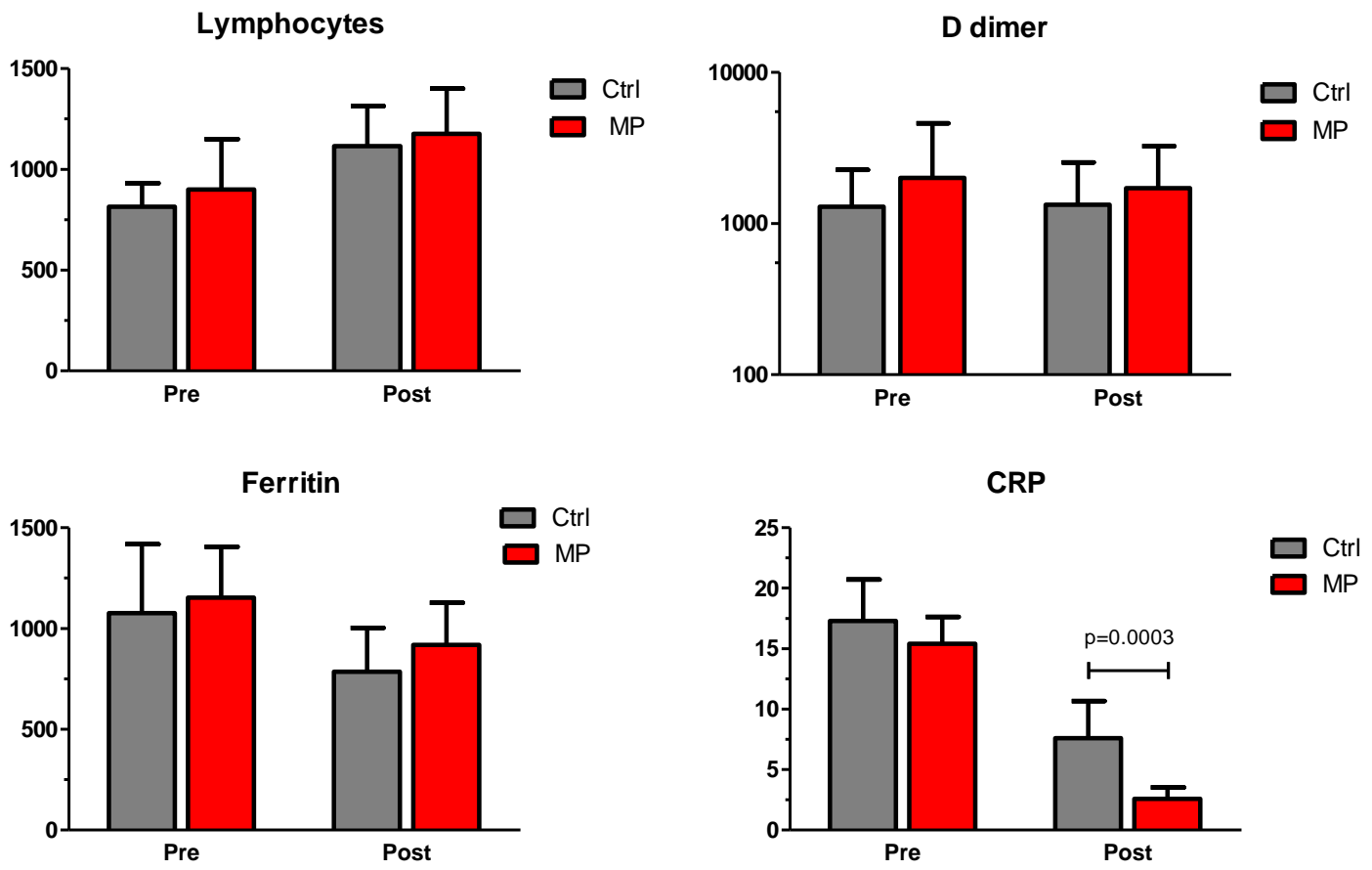
Figure 3

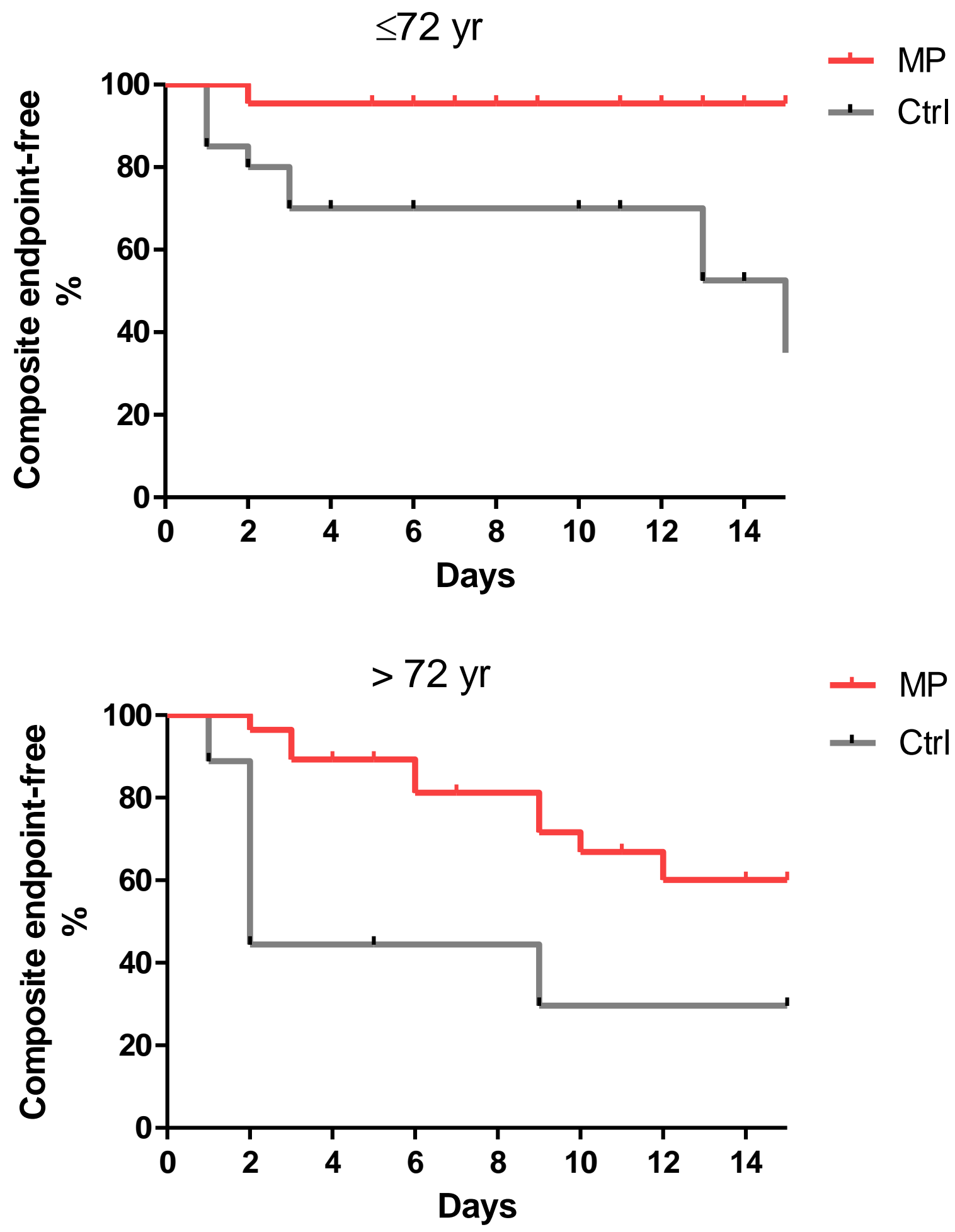


medRxiv preprint doi: https://doi.org/10.1101/2020.06.17.20133579; this version posted June 18, 2020. The copyright holder for this preprint (which was not certified by peer review) is the author/funder, who has granted medRxiv a license to display the preprint in perpetuity.

All rights reserved. No reuse allowed without permission.

Supplementary table. Individual components of the composite endpoint. Number and (\%). MP:

methylprednisolone. ITT: intention-to-treat. PP: per-protocol (>2 doses MP)

\begin{tabular}{|r|c|c|c|}
\hline & Control & MP ITT & MP PP \\
\hline All patients & $\mathrm{n}=29$ & $\mathrm{n}=56$ & $\mathrm{n}=49$ \\
\hline Death & $5(17)$ & $12(21)$ & $9(18)$ \\
\hline ICU & $8(28)$ & $8(14)$ & $4(8)$ \\
\hline NIV & $3(10)$ & $6(11)$ & $3(6)$ \\
\hline \multicolumn{4}{|c|}{$\mathrm{n}$} \\
\hline$\leq 72 \mathrm{yr}$ & $\mathrm{n}=20$ & $\mathrm{n}=25$ & $\mathrm{n}=22$ \\
\hline Death & $1(5)$ & $0(0)$ & $0(0)$ \\
\hline ICU & $8(40)$ & $4(16)$ & $1(4)$ \\
\hline NIV & $1(5)$ & $0(0)$ & $0(0)$ \\
\hline \multicolumn{4}{|c|}{} \\
\hline$>72 \mathrm{yr}$ & $\mathrm{n}=9$ & $\mathrm{n}=31$ & $\mathrm{n}=27$ \\
\hline Death & $4(44)$ & $12(42)$ & $9(33)$ \\
\hline ICU & $0(0)$ & $4(13)$ & $3(11)$ \\
\hline NIV & $2(22)$ & $6(19)$ & $3(11)$ \\
\hline
\end{tabular}


medRxiv preprint doi: https://doi.org/10.1101/2020.06.17.20133579; this version posted June 18, 2020. The copyright holder for this preprint (which was not certified by peer review) is the author/funder, who has granted medRxiv a license to display the preprint in perpetuity.

All rights reserved. No reuse allowed without permission.

\section{Supplementary figure}

Kaplan-Meier plots showing the probability of not occurring the primary composite endpoint (ICU admission, need of NIV or death) of patients in the control group (grey), randomized MP group (red) and preference MP group (green), stratified by age.
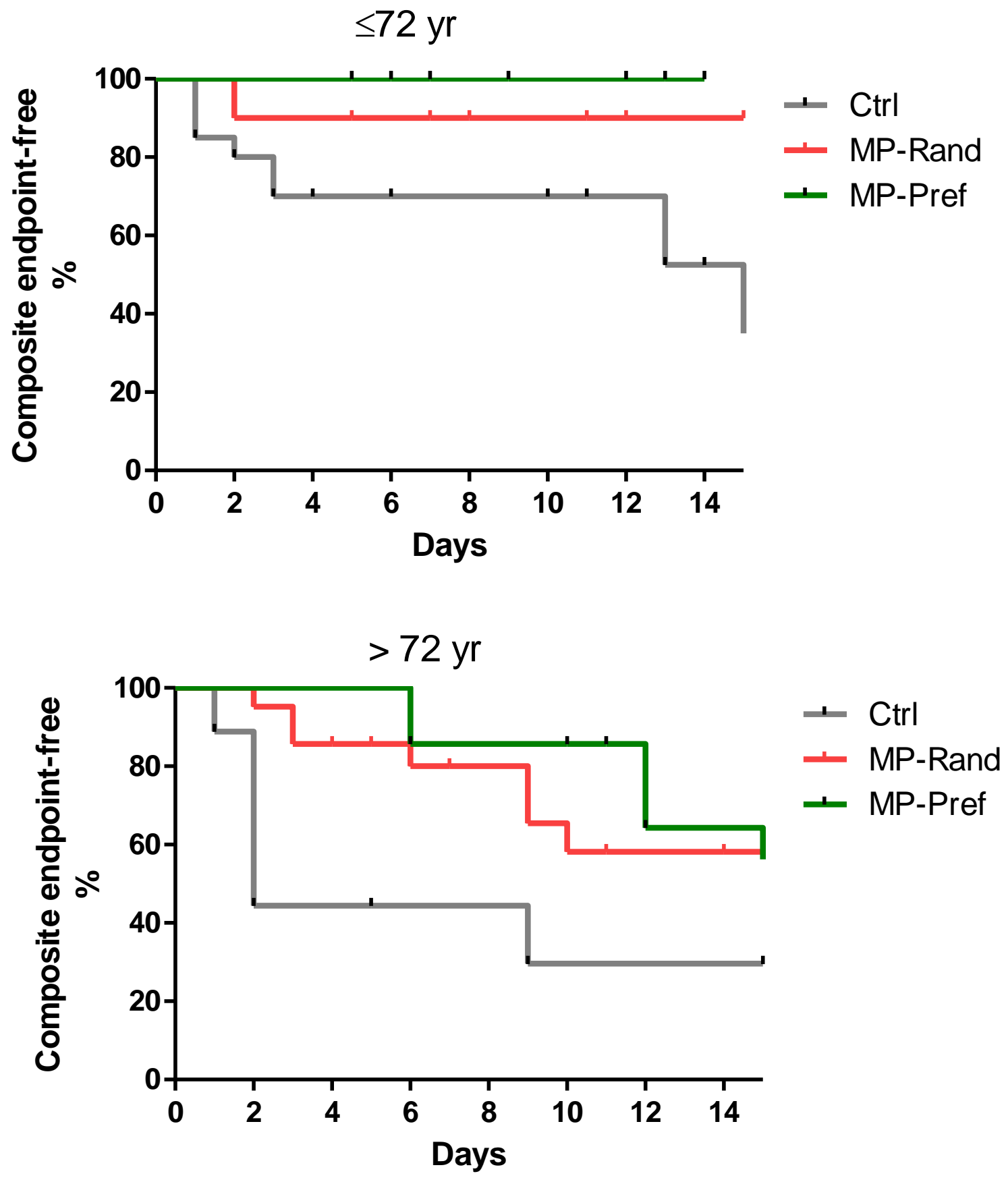